\title{
Phosphorus decreases in Lake Geneva but climate warming hampers the recovery of pristine oligochaete communities whereas chironomids are less affected
}

\author{
Claude $\mathrm{LANG}^{*}$ \\ Former hydrobiologist, Canton of Vaud, Switzerland \\ *Corresponding author: claudelang41@hotmail.com
}

\begin{abstract}
In response to the decrease of phosphorus concentrations in Lake Geneva (France and Switzerland), the mean percentage of individuals belonging to oligochaete species sensitive to low oxygen concentrations has increased in the profundal from $8 \%$ in 1983 to $31 \%$ in 2003. But these species decreased anew from 17\% in 1999 to 2\% in 2009 in the western basin of Lake Geneva (the Small Lake). This shallow basin is more exposed to the effects of warming observed since 1989 than the rest of the lake. To demonstrate these effects, the response of the main species to the increase of organic sedimentation was analysed in the gradient of fine sediment accumulation (FSA), observed in 1999 in the Small Lake. As expected, the abundance of four species classified as sensitive to low oxygen concentrations - Stylodrilus lemani, Embolocephalus velutinus, Bichaeta sanguinea, Paracladopelma nigritula gr. - decreased with the increase of FSA whereas the inverse relationship was observed for four species classified as tolerant Potamothrix vejdovskyi or very tolerant $\mathrm{P}$. hammoniensis, P. heuscheri, and Tubifex tubifex. In contrast, the abundance of three species was not correlated with FSA: Stylodrilus heringianus and Micropsectra contracta both classified as sensitive, Limnodrilus hoffmeisteri as tolerant. The first component of a principal component analysis, based on the mean abundance per transect of the above species, was correlated with FSA. The second component could reflect the long-term increase of water temperature which has been advantageous for Limnodrilus and Micropsectra but disadvantageous for the sensitive oligochaete species less adapted to warm water lakes. Indeed, the abundance of the sensitive oligochaete species and of P. vejdovskyi has decreased from 1994 to 2009 in the Small Lake whereas the abundance of Limnodrilus has increased. Micropsectra and Paracladopelma became more abundant than sensitive oligochaete species. In addition to the effects of temperature, the recovery of the pristine oligochaete community was perhaps impeded in 2009 because the transfer of organic matter to the sediment was increased by the impact of fish (mostly Coregonus) feeding selectively on zooplankton. Finally, many micro pollutants (pesticides, drugs, and other substances) which are present in the lake could have negatively affected sensitive oligochaete species.
\end{abstract}

Key words: Chironomidae; climate change; eutrophication; Oligochaeta; zoobenthos.

Received: November 2015. Accepted: February 2016.

\section{INTRODUCTION}

The impact of climate warming on lakes can undermine the positive effects of the decrease of phosphorus inputs so that the ecological status observed before the onset of man-made eutrophication is not restored as expected (Schindler, 2009). For instance, Lake Maggiore (Italy and Switzerland) is recovering from man-made eutrophication (Guilizzoni et al., 2012) but the responses of its planktonic communities (algae and cladocerans) were affected by the warming which produces in some cases effects similar to those of eutrophication. In addition, the impact of fish predation and of chemical pollution (DDT, mercury) must be integrated in a complex set of interaction to explain the path followed by this lake. Similarly, in Lake Bourget and Annecy (both in France) and Lake Geneva (France and Switzerland), long-term changes in cladoceran communities resulted from interactions between climate warming, nutrient status, and intensity of fish predation on zooplankton (Alric et al., 2013). In these three lakes, the expansion of hypoxia has also been related to warmer air temperatures (Jenny et al., 2014).

In this present study, the composition of oligochaete and chironomid communities colonizing deep sediment $(35-309 \mathrm{~m})$ was used to assess how the ecological status of Lake Geneva has changed between 1957 and 2009. This large lake (mean depth $150 \mathrm{~m}, 580 \mathrm{~km}^{2}$ ), has been affected by major environmental changes between 1957 and 2009 which have been well studied by several regional and international organizations. First, mean total phosphorus concentrations in the water column (from the surface to $309 \mathrm{~m}$ deep) which have increased from $12 \mathrm{mg}$ $\mathrm{m}^{-3}$ in 1957 to $89 \mathrm{mg} \mathrm{m}^{-3}$ in 1977 decreased afterwards to $23 \mathrm{mg}$ in 2009 (Lazzarotto et al., 2011). But the positive effects of this recovery from man-made eutrophication were impeded by the increase from 1969 to 2009 of water temperature which has modified several limnological and biological characteristics of the lake (Anneville et al., 2013). For instance, the increase of water column stability and of incident light has a long term positive impact on phytoplankton productivity which did not decreased as 
expected from the decrease of phosphorus (Tadonléké et al., 2009). In addition, the abundance of some species of fish (mostly Coregonus ssp.) which has increased in response to the declining concentration of phosphorus (Gerdeaux, 2004) has an increased impact on zooplankton (Tadonléké et al., 2009). Finally, many micro pollutants have been detected in the water, the sediment, molluscs and fish of Lake Geneva (Loizeau et al., 2013). The combined effects of these substances have negatively affected several species of planktonic algae in Lake Geneva (Gregorio et al., 2012). And they could have the same negative effect on other species as well, especially those living in deep sediments (such as oligochaetes and chironomids) which are located at the receiving end of all processes in the lake (Wiederholm, 1980).

As these benthic communities change according to the amount and quality of the organic matter settling on the bottom (Lang and Hutter, 1981; Fuentes et al., 2013), the increase of sedimented organic matter, associated with the increase of eutrophication, means more food but less oxygen available at the sediment-water interface. Therefore, the ratio of species sensitive to low oxygen concentrations to those species tolerant of low concentrations was used to document how the conditions have changed since 1955, used as a reference for the state of ecological integrity of Lake Geneva (Juget, 1958).

From 1955 to 1983, the increase of eutrophication was indicated by the decreasing abundance of the sensitive oligochaete species prevailing in 1955, and the increase of the very tolerant species scarce in 1955 (Juget, 1958; Lang, 1985). From 1983 to 2003, the inverse trend was observed as predicted by the decrease of phosphorus in the water (Lods-Crozet and Reymond, 2004). However, in 2005 and 2009, the sensitive species of oligochaetes decreased anew, whereas sensitive species of chironomids increased in two different areas of Lake Geneva (LodsCrozet and Reymond, 2006; Lods-Crozet, 2011). This change suggests that the positive effects of the decrease of phosphorus on zoobenthos were impeded by the increase of the other stressors presented above.

This study tries to explain why the recovery of zoobenthos was reversed in 2009 in the western basin of Lake Geneva, called the Small Lake. This basin is more exposed to the effects of climate warming than the main basin, called the Large Lake, because of its mean depth of $41 \mathrm{~m} v s 171 \mathrm{~m}$. As demonstrated by Rasmussen and Rowan (1997), the local variations of fine sediment accumulation (FSA) interact with lake trophic state as determinant of benthic community composition. Therefore the gradient of FSA present in the Small Lake (Lang 2000) was used to observe how the oligochaete and chironomid species react to the increase of this variable after Lake Geneva become warmer. The increase of FSA was used as a proxy for organic sedimentation (Rasmussen and
Rowan, 1997; Lang 2000). The decrease of sensitive species characteristic of oligotrophic conditions was predicted as well as the increase of the very tolerant species characteristic of eutrophic conditions. Species which did not demonstrate a clear-cut response could have been affected by the increase of temperature or by other factors such as changes in the pelagic-benthic coupling or the impact of micro pollutants on sensitive species.

\section{METHODS}

The indicative value of the main species was tested anew from 186 sediment cores of $16 \mathrm{~cm}^{2}$ each collected with a core sampler in the Small Lake (surface $81 \mathrm{~km}^{2}$ ). In 1999,159 cores were collected on 22 transects $500 \mathrm{~m}$ apart (Lang, 2000). As the cores were located $500 \mathrm{~m}$ apart on each transect, the entire profundal area ( $37 \mathrm{~m}$ to $76 \mathrm{~m}$ ) was covered by a regular grid. The profundal was divided into three areas numbered 1,2 , and 3 from west to east (Fig. 1). They corresponded to the three basins (named Chevrens, Tougues, and Nyon) of the Small Lake (70 m to $76 \mathrm{~m}$ deep), which are separated from one another by sills ( $50 \mathrm{~m}$ to $55 \mathrm{~m}$ deep). In addition to the 22 transects covering these three areas, an additional transect (numbered 23) consisted of 27 cores that were collected in 2006 (Lods-Crozet, 2011) from the sill (area 4) separating the Small Lake from the Large Lake (surface $498 \mathrm{~km}^{2}$ ).

In the laboratory, the thickness of the three layers present in each $30 \mathrm{~cm}$ long sediment core was measured: the brown surficial layer, the intermediate black layer, the grey or brown compact layer beneath. The thickness of the black layer (TBL) was used to indicate the intensity of fine sediment accumulation used as a proxy for organic sedimentation (Lang, 2000). Then, oligochaetes and chironomids, separated from the sediment with a $0.2 \mathrm{~mm}$ sieve, were mounted on microscopic slides and identified to the species or the groups of species (Tab. 1). Species were classified into three groups according to their decreasing tolerance to low oxygen concentrations and pollutants as sensitive (1-6), tolerant (7-10) and very tolerant (11-13) according to previous studies (Lang, 2009). Some species (7-9 and 11-13) were analysed as a group because all the immature individuals could not be identified without doubt. However, the contribution of Potamothrix moldaviensis to the group of species 7-9 was small because most of the mature individuals identified belonged to a Limnodrilus species and the aspect of most of the immature individuals indicated also that they belonged to $L$. hoffmeisteri.

Data analysis was made with the IBM SPSS statistical package version 21. First, relationships between the presence and the absence (denote by 1 or 0 ) of species and the intensity of fine sediment accumulation were analysed. The 186 cores were divided into four groups according to the quartile values of thickness of the black layer (TBL): 


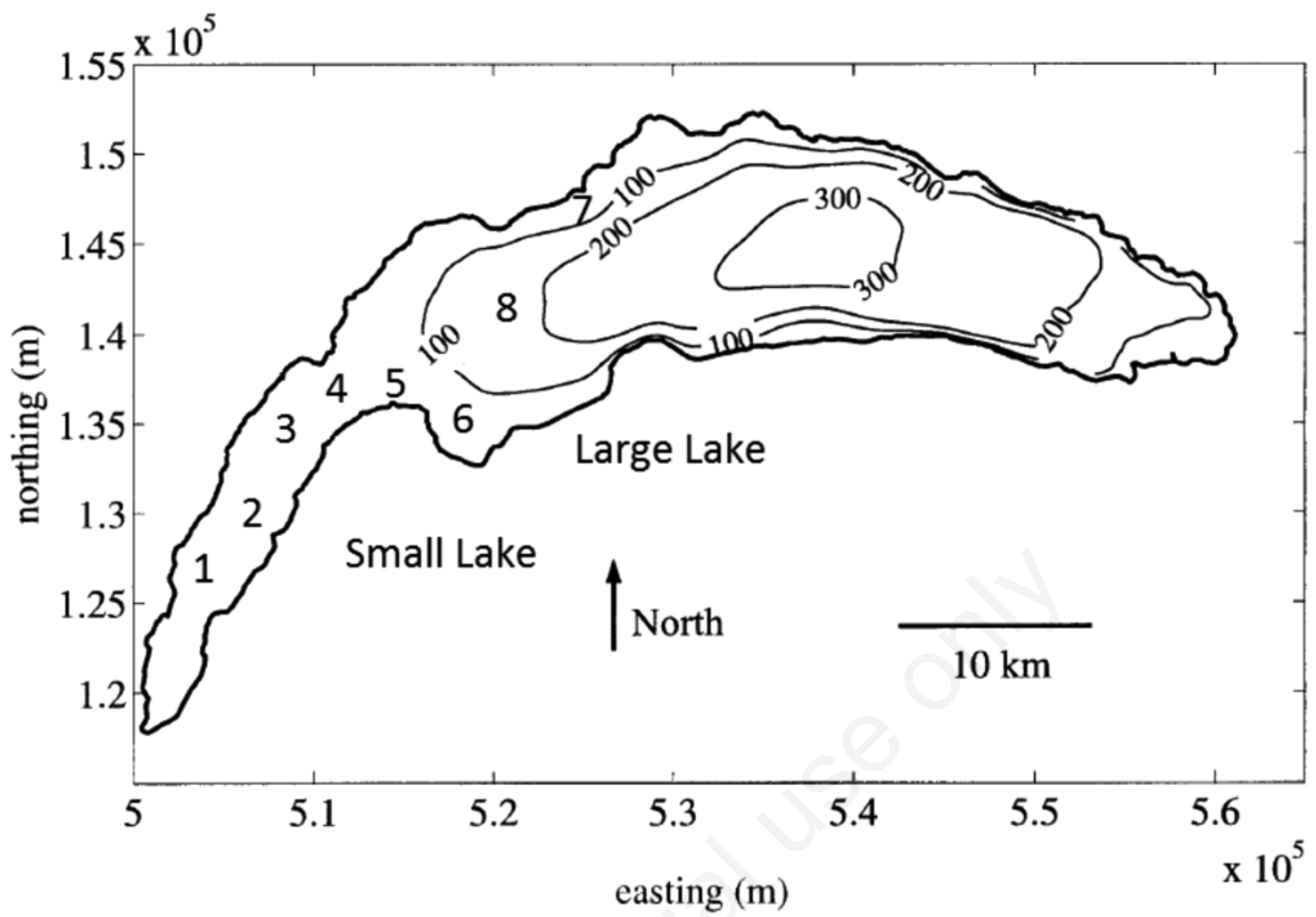

Fig. 1. Location in Lake Geneva of the areas used in this study. Small Lake: areas 1-3 visited in 1994, 1999, 2009; area 4 in 2006; Large Lake: areas 5-6 visited in 1955, area 7 visited in 1990, 1993, 1998, 2005, area 8 visited in 1978, 1983 and 2003. Area 8 covers the western half of the Large Lake. Isobaths $100 \mathrm{~m}, 200 \mathrm{~m}$ and $300 \mathrm{~m}$ are indicated as well as the coordinates of the national map of Switzerland.

Tab. 1. Percentage of cores in which oligochaetes and chironomids species are present in four classes of increasing thickness (cm) of the black layer in sediment cores taken in Lake Geneva (Small Lake). N indicates the number of cores present in each of the 4 classes of values. Species: (1) Embolocephalus velutinus Grube; (2) Bichaeta sanguinea Bretscher; (3) Stylodrilus lemani (Grube); (4) Stylodrilus heringianus Claparède; (5) Micropsectra notescens; (6) Paracladopelma nigritula gr. ; (7) Limnodrilus hoffmeisteri (Claparède); (8) Limnodrilus profundicola (Verrill); (9) Potamothrix moldaviensis (Vejdovskyi and Mrazek); (10) Potamothrix vejdovskyi (Hrabe); (11) Potamothrix hammoniensis (Michaelsen); (12) Potamothrix heuscheri Bretscher; (13) Tubifex tubifex (Müller). The probability associated with the Mantel-Haenszel $\mathrm{Chi}^{2}$ test for trend is indicated.

\begin{tabular}{|c|c|c|c|c|c|}
\hline Species & $\begin{array}{l}0-6 \mathrm{~cm} \\
\mathrm{~N}=46\end{array}$ & $\begin{array}{c}7-10 \mathrm{~cm} \\
\mathrm{~N}=48\end{array}$ & $\begin{array}{c}11-16 \mathrm{~cm} \\
\mathrm{~N}=45\end{array}$ & $\begin{array}{c}17-22 \mathrm{~cm} \\
\mathrm{~N}=47\end{array}$ & $\begin{array}{l}\mathrm{Chi}^{2} \text { trend } \\
\text { Probability }\end{array}$ \\
\hline 1 & 60.9 & 31.3 & 17.8 & 8.5 & 0.000 \\
\hline 2 & 19.6 & 31.3 & 17.8 & 2.1 & 0.004 \\
\hline 3 & 8.7 & 8.3 & 2.2 & 0 & 0.022 \\
\hline 4 & 37.0 & 27.1 & 24.4 & 21.3 & 0.104 \\
\hline $2-4$ & 50.0 & 52.1 & 37.8 & 23.4 & 0.002 \\
\hline $1-4$ & 84.8 & 68.8 & 44.4 & 27.7 & 0.000 \\
\hline 5 & 47.8 & 35.4 & 40.0 & 29.8 & 0.136 \\
\hline 6 & 21.7 & 4.2 & 0 & 0 & 0.000 \\
\hline $5-6$ & 63.0 & 37.5 & 40.0 & 29.8 & 0.009 \\
\hline $1-6$ & 95.7 & 77.1 & 64.4 & 48.9 & 0.000 \\
\hline $7-9$ & 23.9 & 41.7 & 33.3 & 29.8 & 0.911 \\
\hline 10 & 30.4 & 68.8 & 84.4 & 76.6 & 0.000 \\
\hline $11-13$ & 47.8 & 79.2 & 91.1 & 87.2 & 0.000 \\
\hline
\end{tabular}


0-6 $\mathrm{cm}, 7-10 \mathrm{~cm}, 11-16 \mathrm{~cm}, 17-22 \mathrm{~cm}$. The numbers of cores in which the species were present or absent in these four groups were compared by the Mantel- Haenszel Chi ${ }^{2}$ test for trend (called linear by linear in SPSS) to detect a linear association between the four rows (TBL) and the two columns ( 1 or 0$)$. In the same way, the JonckheereTerpstra test was used to detect a trend between the numbers $\mathrm{m}^{-2}$ of selected species and the 4 groups of black sediment thickness.

In addition, as most species were absent from many cores (Tab. 1), the variation of their abundance was analysed at the level of the 23 transects instead of the 186 cores. To do this, the mean number $\mathrm{m}^{-2}$ of individuals belonging to each species or group of species was computed from the cores present on each transect. The mean thickness of the black layer per transect was computed in the same way. As a result, the zero values present in the 186 cores were eliminated from the 23 transects. First, Spearman rank correlations between numbers of individuals of each species and TBL were computed for the 23 transects. Finally, the relationships between the mean numbers of each species was analysed by a principal component analysis based on the 23 transects. Then the scores for each component were correlated with the thickness of the black layer and depth used as a proxy for temperature.

For each transect the numbers of individuals belonging to the sensitive species (SS), expressed as a percentage, were computed from the numbers of individuals belonging to the species of Tab. 1 combined in three ways to compute three indices indicating different aspects of the ecological recovery of deep sediments (Lang, 2009):

SS1 $(\%)=$ species $1-4 /($ species $1-4+$ species $7-13) \quad$ (eq. 1) SS2 $(\%)=$ species $1-4 /($ species $1-4+$ species $11-13) \quad$ (eq. 2$)$ SS3 $(\%)=$ species $1-6 /($ species $1-6+$ species $11-13) \quad$ (eq. 3$)$

In SS2 and SS3, the numbers of individuals belonging to the sensitive species (oligochaetes only or oligochaetes and chironomids combined) were reported to those of the very tolerant species of oligochaetes. In that way, species, which responded more to the increase of water temperature than to the decrease of total phosphorus, were excluded. In contrast, SS1 was based on the number of sensitive oligochaetes reported to the total number of oligochaetes. In addition, SS1 was negatively correlated with total phosphorus (TP) concentrations $\left(\mathrm{mg} \mathrm{m}^{3}\right)$ in the water (Lang, 1990):

SS1 $(\%)=80.29-8.35 \mathrm{TP}^{0.5} \mathrm{r}^{2}=0.81 \mathrm{n}=15$

(eq. 4)

This empirical relationship was based on 15 surveys made in eight lakes of Western Europe and three large lakes of North America studied before they were affected by the increase of water temperature (Lang, 1990). It was used to compare the value of SS1 observed in each sampling locations to that predicted from phosphorus.

In the second part of this study, the reactions of the species to the increase of TBL were used to interpret anew results from: i1) two surveys made in 1983 (Lang, 1985) and 2003 in the Large Lake (Lods-Crozet and Reymond, 2004); ii) of three surveys made in 1994, 1999 (Lang, 2000) and 2009 (Lods-Crozet, 2011) in the Small Lake (Fig. 1). The methods and the sampling design used in 1994 were exactly the same as in 1999 , except that the chironomid species collected in 1994 were not identified. In contrast, the 2009 survey was based on a different design with only two sampling stations located in each of the three basins. In each basin, one station was located at a depth of $40 \mathrm{~m}$ on the northern side of the lake, the other at $70 \mathrm{~m}$ or $76 \mathrm{~m}$ in the middle of the lake. In each station, five sediment samples of $225 \mathrm{~cm}^{2}$ were taken with an Ekman grab. However, the analysis was based on 22 samples only because results for the oligochaetes present in eight samples were missing. As a result, the 2009 survey is less likely to represent the whole profundal of the Small Lake because it is based only on six sites, but intensively studied, instead of the 159 sites visited in 1994 and 1999. In addition, a sieve with a mesh size of $0.3 \mathrm{~mm}$ was used in 2009 instead of $0.2 \mathrm{~mm}$ in 1994 and 1999. Finally, data from 22 samples (each $225 \mathrm{~cm}^{2}$ ) that were collected in 1955 from a mean depth of 63 m using an Ekman grab (Juget 1958), were used as a reference for the pristine state of Lake Geneva. The areas 5 (14 samples) and 6 (8 samples) visited in 1955 were located respectively $2 \mathrm{~km}$ and $5.5 \mathrm{~km}$ east from the area 4 sampled in 2006 (Fig. 1).

\section{RESULTS}

Mean and median water temperatures measured at a depth of $50 \mathrm{~m}$ in Lake Geneva were higher during the years 1989 to 2008 than during the years 1969 to 1988 (Tab. 2). The five warmer years recorded between 1989 and 2008 were warmer $\left(6.99-7.09^{\circ}\right)$ that those between

Tab. 2. Comparison of the mean annual temperatures $\left({ }^{\circ} \mathrm{C}\right)$ recorded in Lake Geneva at a depth of $50 \mathrm{~m}$ between 1969 and $1988(n=20)$ and between 1989 and $2008(n=20)$. Temperatures measured in the middle of the Large Lake above the deepest area (Lazzarotto et al., 2011).

\begin{tabular}{lll} 
Statistics & 1969 & 1989 \\
& 1988 & 2008 \\
Mean & 6.31 & 6.66 \\
Minimum & 5.87 & 5.78 \\
\hline Quartile 1 & 6.07 & 6.53 \\
Quartile 2 & 6.33 & 6.61 \\
\hline Quartile 3 & 6.59 & 6.97 \\
Maximum & 6.80 & 7.09 \\
\hline
\end{tabular}


1969 and $1988\left(6.59-6.80^{\circ}\right)$. The increasing trend for temperature from 1969 to 2008 was significant $\left(r_{s}=0.400\right.$, $\mathrm{P}=0.011, \mathrm{n}=40$ ). The observed increase seems small but it has already affected the development of planktonic communities and the timing of the reproduction of some species of fish (Anneville et al., 2013).

In the Small Lake, the thickness of the black layer within the sediment (TBL), which decreased from basin 1 to the area 4 (Fig. 2), was inversely related to the thickness of the compact layer (lacustrine clay or chalk) located beneath TBL. In contrast, TBL was directly related to the total thickness of the sediment collected in the $30 \mathrm{~cm}$ long cores. Finally, the median thickness of the brown layer, which was more or less unchanged in area 4, in basin 3 and 2 decreased strongly in basin 1 . This distribution indicated that fine sediment accumulation decreased from basin 1 to basin 3 and was very low in area 4 .

The species present in the 186 cores were divided into three categories according to their reaction to the increase of the black layer in the sediment (Tab. 1): those whose occurrence decreased (species 1-3, 6), whose occurrence increased (species 10-13), and those which did not show a clear trend (species 4, 5, 7-9). The analysis based on the number of individuals $\mathrm{m}^{-2}$ indicated the same trends for species or group of species (Fig. 3). Note how the total abundance of the sensitive species (1-6) was inversely re- lated to that of the very tolerant species when TBL increases (Fig. 3). This relationship explained why the SS3 index was based on these two groups of variables. Spearman rank correlations between mean TBL and the mean abundance of each species or group of species per transect (Tab. 3) indicated that the species or group of species can be classified into two extreme groups: those which are negatively (species 1) or positively (species 11-13) correlated with the increase of TBL. For species 4 and the group of species 7-9, the correlation was not significant. The principal component analysis based on the mean abundance of species per transect showed the relative position of each species according to component 1 and 2 (Fig. 4). Because component 1 was significantly correlated with TBL $\left(\mathrm{R}^{2}=0.689\right.$, Fig. 5), the species followed each other on Fig. 4 as in a gradient of fine sediment accumulation modified by the effect of component 2. Mean value per transect of TBL decreased from basin 1 to 3 whereas it was very low on the sill (area 4) separating the Small Lake from the Large Lake (Fig. 5). Component 2 which was neither correlated with TBL or mean depth $\left(\mathrm{R}^{2}=0.001, \mathrm{n}=23\right)$ could reflect the effects (either positive or negative) on some species of the long term increase of water temperature recorded in Lake Geneva from 1969 to 2008 (Tab. 2), among other factors (see the Discussion).

The three indices based on the percentage of individu-

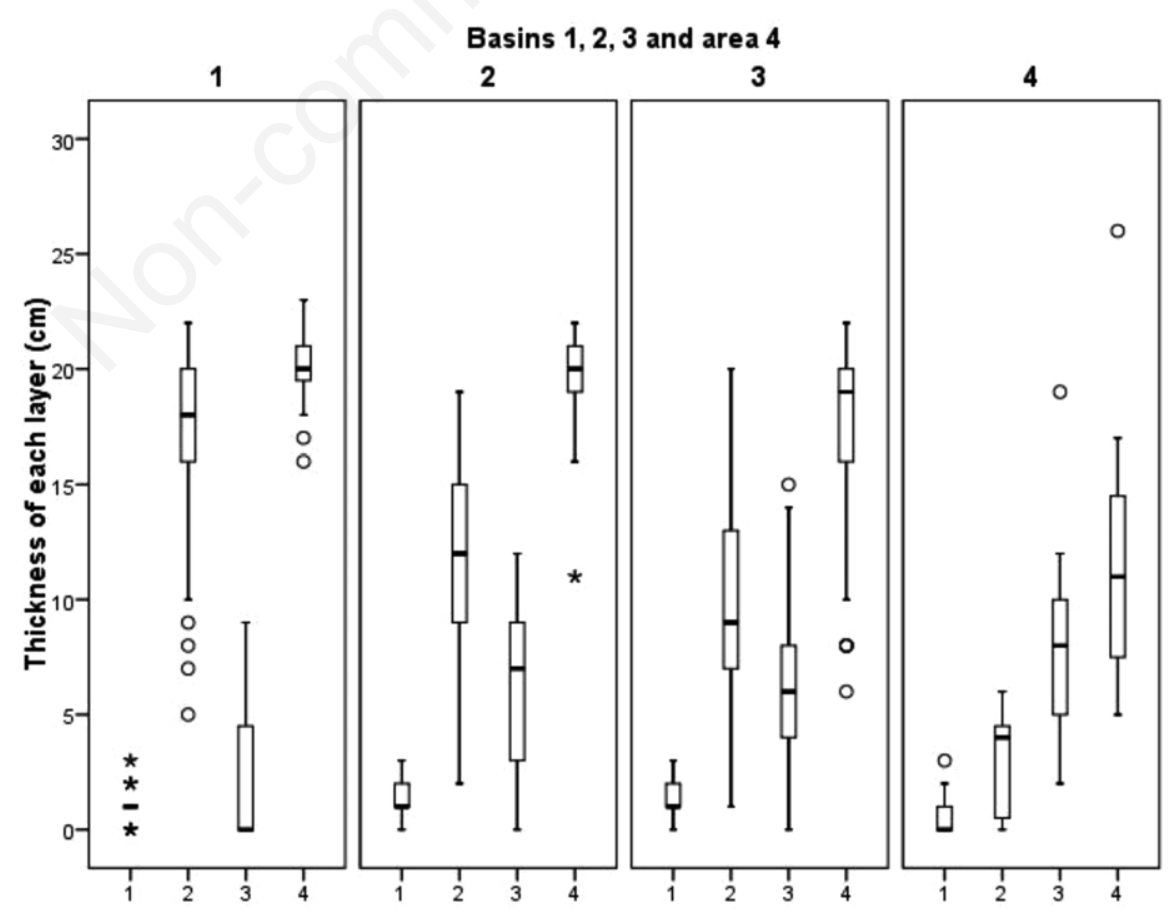

Fig. 2. Box plots describing how the thickness $(\mathrm{cm})$ of the three layers present within the sediment changes between the basins $1,2,3$, and the area 4 . On the $\mathrm{x}$ axis, variable 1 indicates the thickness of the surficial brown layer, variable 2 of the black layer, variable 3 of the compact layer, variable 4 of the 3 layers together. 
als belonging to the sensitive species were negatively correlated with TBL. The strongest correlation was observed for SS3 (Fig. 6), the weakest for SS1, based on the percentage of individuals belonging to sensitive species in the oligochaete community (Fig. 7) whereas the correlation for SS2 was intermediate $\left(\mathrm{R}^{2}=0.640, \mathrm{n}=23\right)$. These relationships indicated that, if TBL is a reliable proxy for organic sedimentation (see the Discussion), the SS3 index is a better indicator of changing trophic conditions than SS2 or SS1, especially when the sensitive species of chironomids became more abundant than the sensitive species of oligochaetes in a warmer lake.Mean concentrations of total phosphorus have decreased from $75.4 \mathrm{mg}$ in 1983 to 32.8 $\mathrm{mg} \mathrm{m}^{-3}$ in 2003 in the water of the Large Lake (Lazzarotto et al., 2011). Oligochaete communities, present in the area 8 of the Large Lake (Fig. 1), have been studied in 1983 (Lang 1985) and 2003 (Lods-Crozet and Reymond 2004). In both surveys, the relative importance of the 3 most tolerant species of oligochaetes increased with depth (Fig. 8). In contrast, the abundance of the sensitive species of oligochaetes followed the inverse trend. Between the depths of $35 \mathrm{~m}$ and $100 \mathrm{~m}$, the individuals of these species which formed $7.7 \%$ of the oligochaete community in 1983 increased to $30.8 \%$ in 2003 as predicted from the decrease of phosphorus. The same increase was observed between

Tab. 3. Spearman rank correlations between the thickness of the black layer in the sediment and the numbers of individuals $\mathrm{m}^{-2}$ of oligochaete and chironomid species (see Tab. 1) computed from 23 transects located in the Small Lake.

\begin{tabular}{lcc} 
Species & Correlation & Probability \\
1 & -0.682 & 0.000 \\
$2-4$ & -0.440 & 0.036 \\
\hline $1-4$ & -0.683 & 0.000 \\
4 & -0.101 & 0.647 \\
\hline $5-6$ & -0.499 & 0.015 \\
5 & -0.436 & 0.038 \\
\hline 6 & -0.444 & 0.034 \\
$1-6$ & -0.707 & 0.000 \\
\hline $7-9$ & -0.201 & 0.358 \\
10 & +0.388 & 0.067 \\
\hline $11-13$ & +0.592 & 0.003 \\
\hline
\end{tabular}

Thickness of the black layer $(\mathrm{cm})$

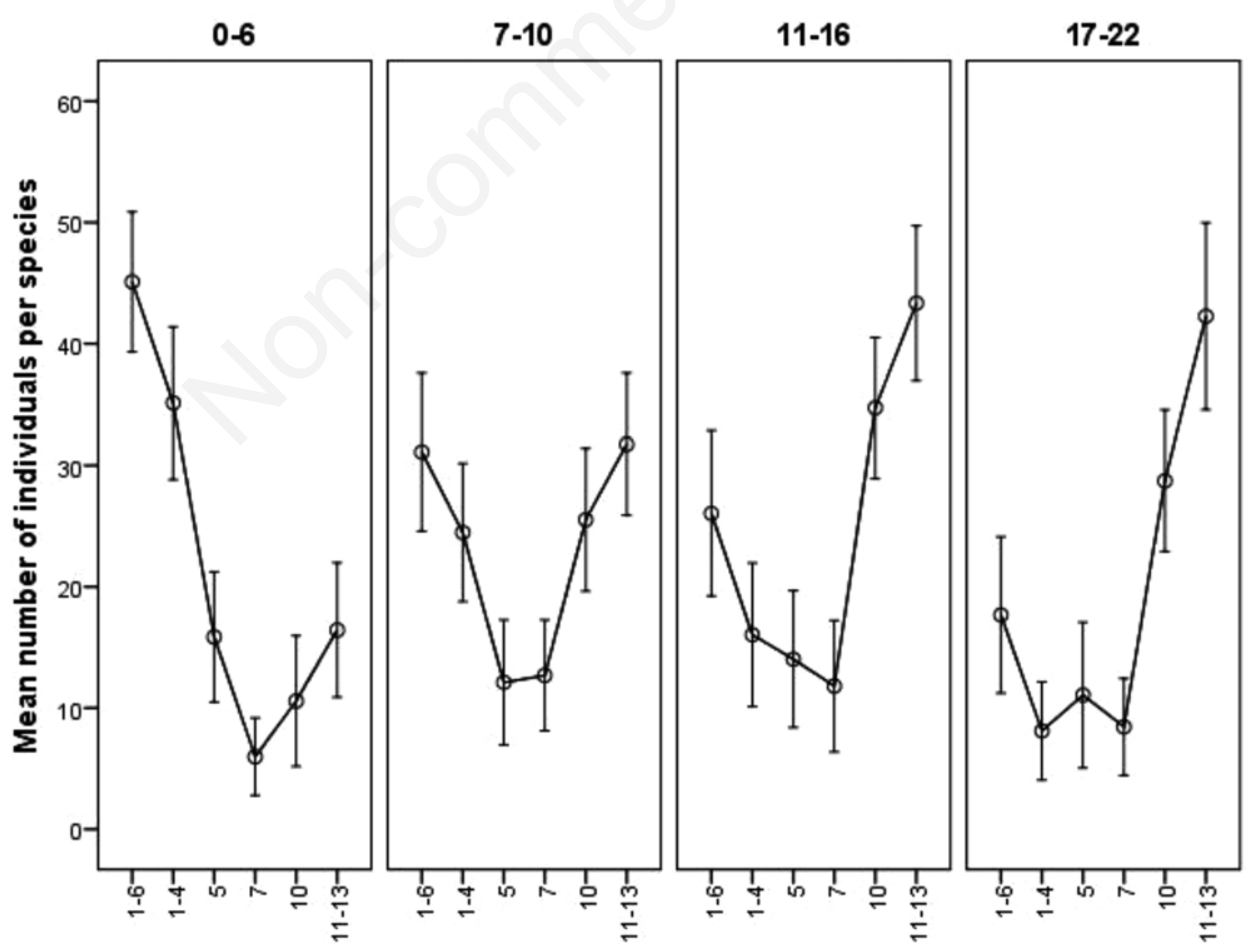

Fig. 3. Changes in the mean numbers of individuals $\mathrm{m}^{-2}$ with $95 \%$ confidence intervals (square root transformed) of species or groups of species according to the increasing thickness of the black layer within the sediment. On the $\mathrm{x}$ axis, the digits 1 to 13 correspond to the names of species present on Tab. 1. Jonckheere-Terpstra test for trend (probability) for species 1-6 (0.000), species 1-4 (0.000), species 5 (0.137), species 7 (0.599), species 10 (0.000), species $11-13(0.000)$. 
the depths of $101 \mathrm{~m}$ and $200 \mathrm{~m}$, but it was due mostly to the increase of $S$. heringianus whereas the abundance of E. velutinus was unchanged. Note how the abundance of chironomids followed the increase of sensitive oligochaete species. In 2003, the abundance of the three very tolerant oligochaete species decreased but these positive trends decreased with depth, especially below $200 \mathrm{~m}$. From 1983 to 2003, the abundance of $P$. vejdovskyi decreased between the depths of $35 \mathrm{~m}$ and $100 \mathrm{~m}$, but increased between the depths of $101 \mathrm{~m}$ and $200 \mathrm{~m}$. These changes between 1983 and 2003 suggested an improvement of oxygen concentrations, at least the level of water-sediment interface wherein zoobenthos respires (more details in the Discussion). Indeed, the oxygen concentrations measured in the water column from 1960 to 2009 were always higher than $4 \mathrm{mg} \mathrm{L}^{-1}$ up to a depth of $220 \mathrm{~m}$, often to a depth of 260 $\mathrm{m}$, sometimes to a depth of $280 \mathrm{~m}$, rarely below $300 \mathrm{~m}$ (Lazzarotto et al., 2011).

In the Small Lake, the response of zoobenthos to the decrease of phosphorus was not the same as in the Large Lake (Lang 2000, Lods-Crozet 2011). However, mean total phosphorus concentrations have decreased in the water from $28 \mathrm{mg}$ in 1994 to $12.9 \mathrm{mg} \mathrm{m}^{-3}$ in 2009 but the mean water temperature has increased of $1^{\circ}(70 \mathrm{~m}$ deep $)$ at the same time (Lazzarotto et al., 2011). The abundance of the sensitive oligochaete species, which was the same in 1994 and 1999, decreased anew in 2009 (Fig. 9). As a consequence, the sensitive chironomids became more abundant than the sensitive oligochaetes in 2009. The two other main changes recorded during this period included a decrease in abundance of $P$. vejdovskyi and a strong increase of $L$. hoffmeisteri. A new comparison was made to detect if the composition of zoobenthos was affected by the different sampling designs used in 1999 and 2009 (see section Methods). It was based on the mean numbers of each species computed from the 22 transects visited in 1999 and the mean numbers computed from the six sites visited in 2009. The changes observed (Tab. 4, columns 8 and 9) were the same as those presented on Fig. 9: sensitive species of oligochaetes became less abundant than sensitive chironomids in 2009, the abundance of $P$. vejdovskyi decreased whereas that of L. hoffmeisteri increased. Note the increased abundance of Paracladopelma between 1999 and 2009 whereas that of Micropsectra did not change.

The oligochaete community present in 2006 in the area 4 (Fig. 9) corresponds to the community observed in 1955 (Tab. 4, column 7), except for the two species (Potamothrix vejdovskyi, P. moldaviensis) which have invaded Lake Geneva later. In 1955 as in 2006, E. velutinus was the most

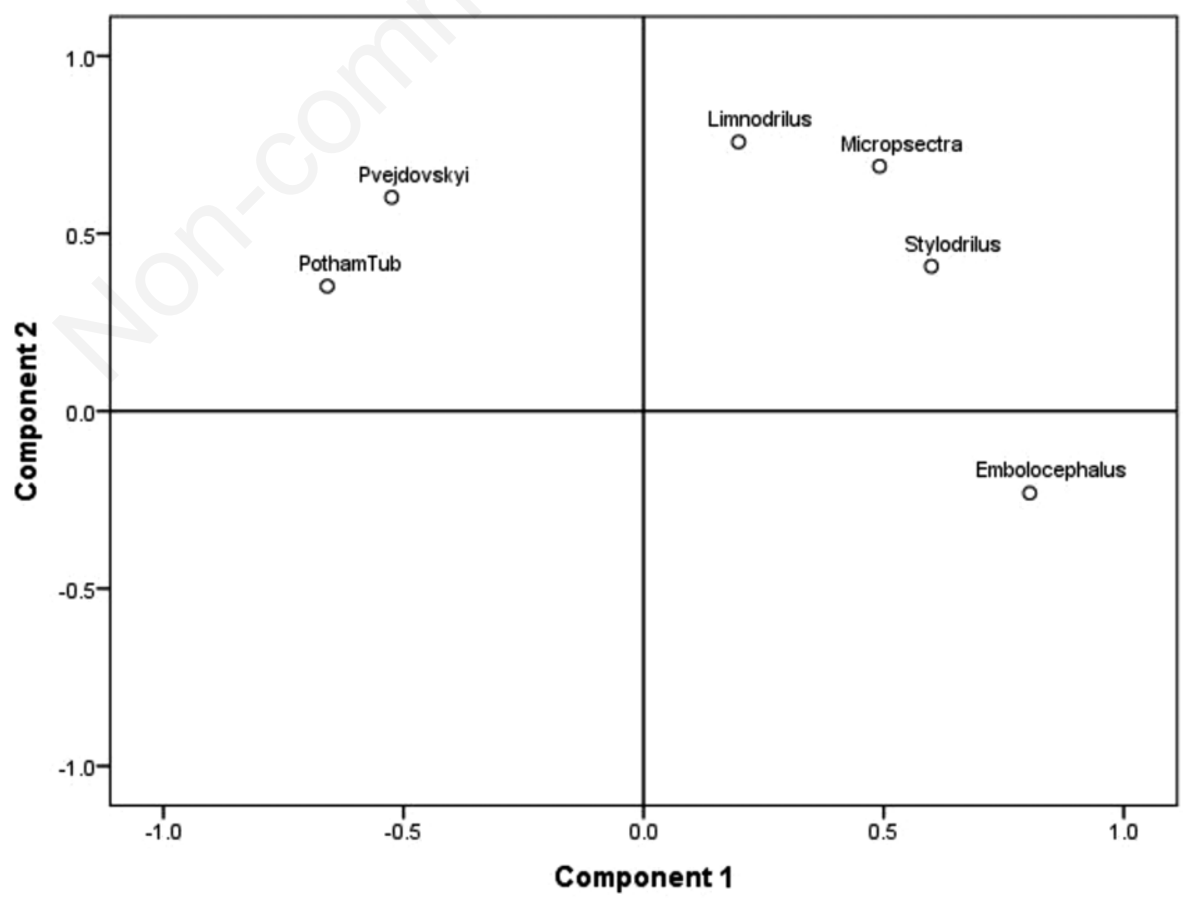

Fig. 4. Factorial plot of components 1 and 2 of a principal component analysis based on the mean numbers $\mathrm{m}^{-2}$ of species or groups of species present in 23 transects located in the Small Lake (basins 1-3 and area 4). Embolocephalus corresponds to species 1 of Tab. 1, Stylodrilus to species 2-4, Micropsectra to species 5, Limnodrilus to species 7, Pvejdovskyi to species 10, PothamTub to species 11-13. Component 1 explained $34.4 \%$ of variance, component $2,27.6 \%$. 


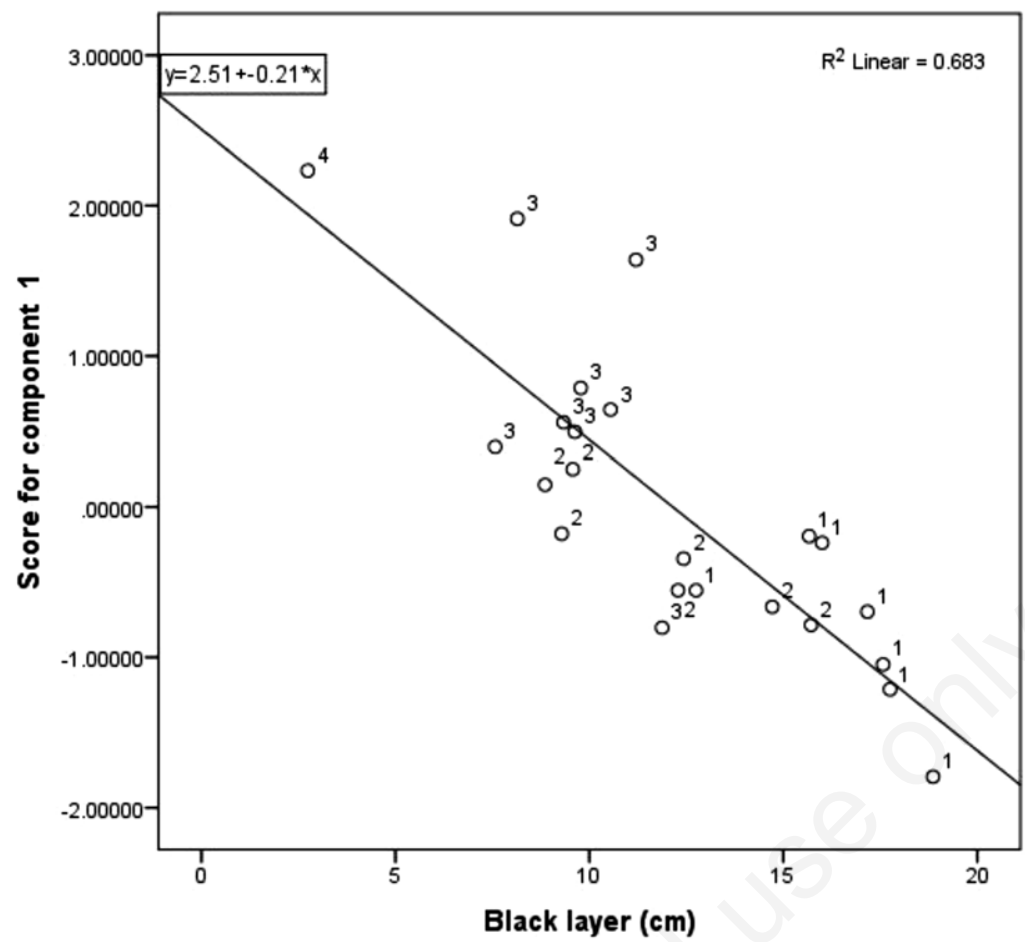

Fig. 5. Relationships between mean thickness of the black layer and scores on component 1 in the 23 transects $(\mathrm{R}=0.689)$. The digits 1 to 3 denote the three different basins present in the Small Lake and digit 4 denotes the area 4 located on the sill separating the Small Lake from the Large Lake (Fig. 1).

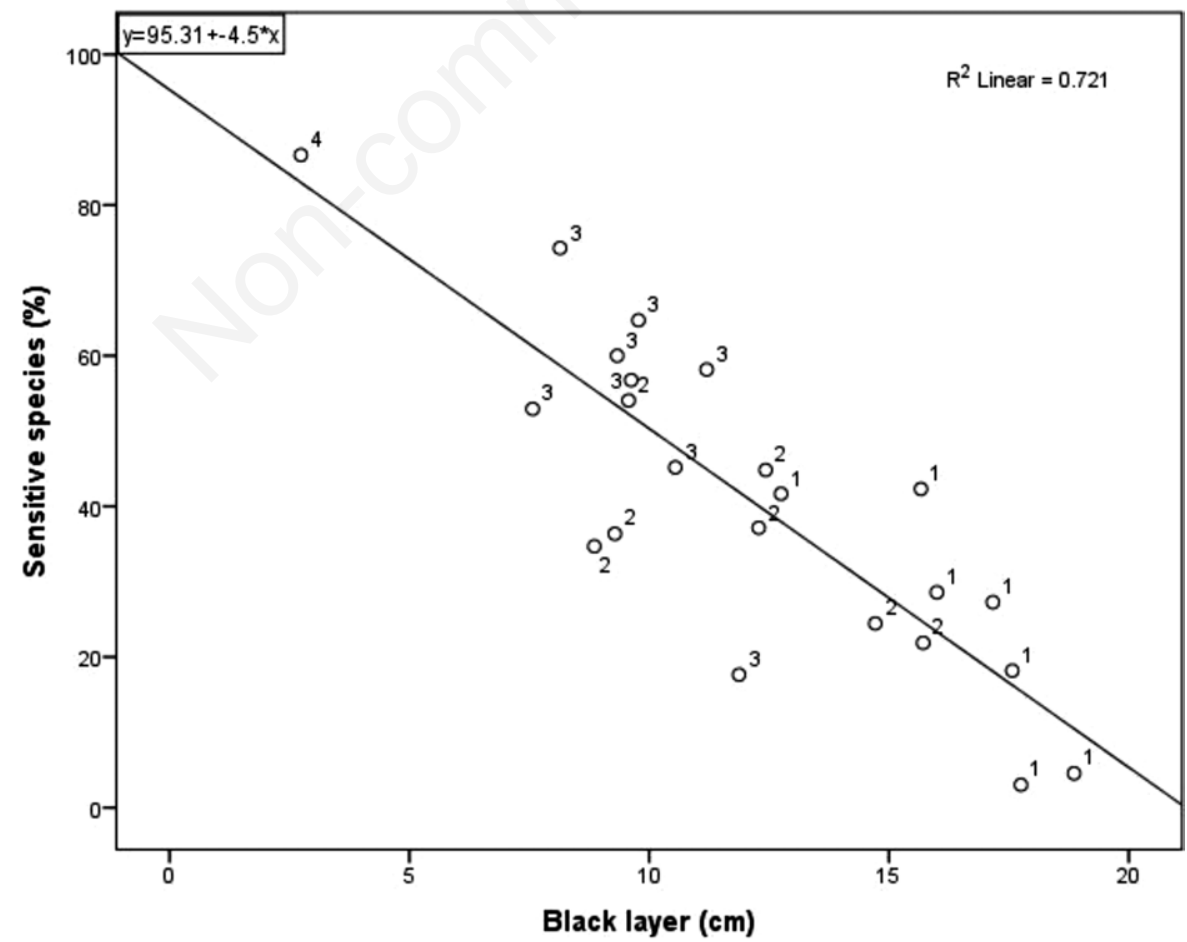

Fig. 6. Relationships between mean thickness of the black layer and the percentage of individuals belonging to the sensitive species (oligochaetes and chironomids) reported to the very tolerant oligochaete species (SS3) in 23 transects located in the Small Lake $\left(\mathrm{R}^{2}=0.721\right)$. 
abundant species whereas the abundance of the three very tolerant species was low. Among the chironomids present, Micropsectra was more abundant than Paracladopelma in both studies: 500 vs 300 individuals $\mathrm{m}^{-2}$ in 2006 .

\section{DISCUSSION}

\section{Black layer and organic sedimentation}

The present study assumes that the thickness of the black layer (TBL) within the sediment can be used as a proxy for organic sedimentation. Two studies previously conducted in Lake Geneva confirm that the oligochaetes react to the increase of organic sedimentation as they react to the increase of TBL (Tab. 4, columns 1-4). In the first study (Lang and Hutter 1981), sediment traps located in two $35 \mathrm{~m}$ deep sites have registered an organic sedimentation of $157 \mathrm{~g} \mathrm{C} \mathrm{m}^{-2}$ and $214 \mathrm{~g} \mathrm{C} \mathrm{m}^{-2}$ year ${ }^{-1}$ respectively, which derived from the inputs of a sewage treatment plant in addition to those of the phytoplanktonic production. As the weight of organic carbon was positively correlated with the oxygen uptake in the sedimented matter collected in the sediment traps (Hutter and Lang, 1981), the increase of organic sedimentation implies a decline in oxygen concentrations at the water-sediment interface (Fuentes et al., 2013) but with more food becoming available for the species well adapted to these conditions. As a consequence, the mean number of individuals belonging to the three most tolerant species - P. hammoniensis, $P$. heuscheri and T. tubifex - increased whereas the sensitive species (species 1-4 of Tab. 1) decreased, especially $E$. velutinus. The numbers of $P$. vejdovskyi increased whereas the mean numbers of $L$. hoffmeisteri, which were low in both conditions, were not significantly different.

The second study made at a depth of $40 \mathrm{~m}$ (Lang, 1989) was based on the observation that, over large areas of Lake Geneva, the sediment consists of pillow-like formations (around $80 \mathrm{~cm}$ wide) separated by trenches (around $20 \mathrm{~cm}$ wide and $5 \mathrm{~cm}$ deep) whose origin is still debated (Brandl et al., 1993). However, sediment analyses have clearly indicated that the organic sedimentation was lower in the trenches, which correspond to erosional conditions, than on the pillows which correspond to depositional ones. As a result, the microbial ecosystem at the top of pillows was metabolically two or three times more active than in the trenches. The black layer was thicker on the pillows than in the trenches. In addition, the redox transition zone from aerobic to anaerobic conditions is located deeper $(6 \mathrm{~cm} v s 0.5 \mathrm{~cm})$ under the sediment surface in the trenches than on the pillows, suggesting that better oxygen conditions are present at the interface. Oligochaete communities reflected these differences. Because the decrease of organic sedimentation, the abundance of $P$. vejdovskyi, $P$. hammoniensis, P. heuscheri and T. tubifex was lower in the trenches than on the pillows.

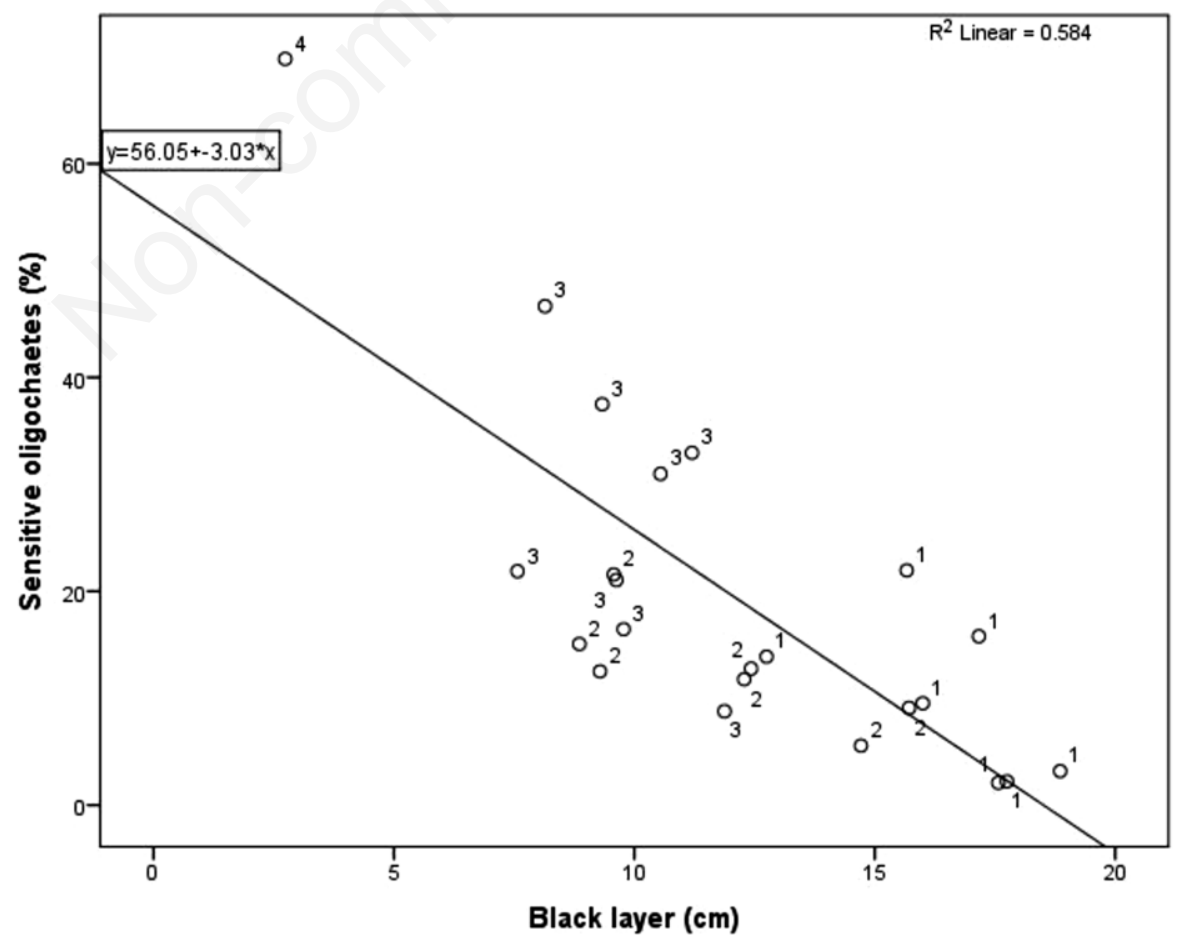

Fig. 7. Relationships between mean thickness of the black layer and the percentage of individuals belonging to the sensitive oligochaete species reported to the total number of oligochaetes $(\mathrm{SS} 1)$ in 23 transects located in the Small Lake $\left(\mathrm{R}^{2}=0.584\right)$. 
Because of better oxygen conditions, E. velutinus, contrary to $S$. heringianus, was relatively more abundant in the trenches. The abundance of Limnodrilus species was not significantly different on the pillows and in the trenches. Because of this small-scale sedimentary patchiness, surveys based on many small cores will indicate more precisely the ecological status of a lake than those based on a few large samples.

Tab. 4. Variations of the mean numbers $\mathrm{m}^{-2}$ of individuals belonging to the species of Tab. 1 in different sites of Lake Geneva in which the organic sedimentation was either low or high. In sites 1 and 2, the organic sedimentation was measured in sediment traps (Lang and Hutter 1981). In site 3, sediment was collected in trenches; in site 4, on pillows (Lang, 1989). In site 5, the black layer within the sediment was less than $11 \mathrm{~cm}$ thick; in site 6 , it was above $10 \mathrm{~cm}$ thick (this present study). Site 7 corresponds to the situation observed in the year 1955 used as a reference for oligotrophic conditions (Juget 1958), sites 8 and 9 correspond to the mean values computed from 22 transects in 1999 and from 6 stations in 2009. Chironomid species were not identified in sites 1 to 4 . N denotes the number of sediment samples. For each species or group of species, the numbers of individuals were compared by the Mann-Whitney test. Mean values underlined indicate that the distribution of numbers was significantly higher in one of the two sites compared.

\begin{tabular}{|c|c|c|c|c|c|c|c|c|c|}
\hline Species & $\begin{array}{l}\text { Low } 1 \\
\mathbf{N}=\mathbf{1} 4\end{array}$ & $\begin{array}{l}\text { High } 2 \\
\mathrm{~N}=14\end{array}$ & $\begin{array}{l}\text { Low } 3 \\
N=64\end{array}$ & $\begin{array}{l}\text { High } 4 \\
N=64\end{array}$ & $\begin{array}{l}\text { Low } 5 \\
N=94\end{array}$ & $\begin{array}{c}\text { High } 6 \\
\mathrm{~N}=92\end{array}$ & $\begin{array}{l}\text { Low } 7 \\
N=22\end{array}$ & $\begin{array}{l}\text { Low } 8 \\
\mathrm{~N}=22\end{array}$ & $\begin{array}{c}\text { High } 9 \\
\mathrm{~N}=6\end{array}$ \\
\hline 1 & 637 & 0 & $\underline{919}$ & 769 & $\underline{591}$ & 115 & 486 & 195 & 47 \\
\hline 2 & 0 & 0 & 0 & 0 & $\underline{272}$ & 68 & 6 & $\underline{165}$ & 0 \\
\hline 3 & 15 & 23 & 0 & 0 & 66 & 7 & 106 & 29 & 15 \\
\hline 4 & $\underline{762}$ & 69 & 794 & 1087 & 385 & 251 & 30 & $\underline{341}$ & 5 \\
\hline $1-4$ & $\underline{1414}$ & 92 & 1713 & 1856 & $\underline{1314}$ & 441 & 628 & $\underline{730}$ & 67 \\
\hline 5 & - & - & - & - & 511 & 536 & 343 & 501 & 191 \\
\hline 6 & - & - & - & - & 93 & 0 & 20 & 7 & $\underline{140}$ \\
\hline $7-9$ & 411 & 671 & 125 & 225 & 279 & 353 & 46 & 340 & $\overline{1108}$ \\
\hline 10 & 3622 & $\underline{11,482}$ & 2131 & $\underline{4050}$ & 751 & 1385 & 0 & 1262 & 285 \\
\hline $11-13$ & 7674 & $\underline{49,800}$ & 575 & $\underline{1525}$ & 1017 & 2391 & 299 & 1922 & 1657 \\
\hline
\end{tabular}

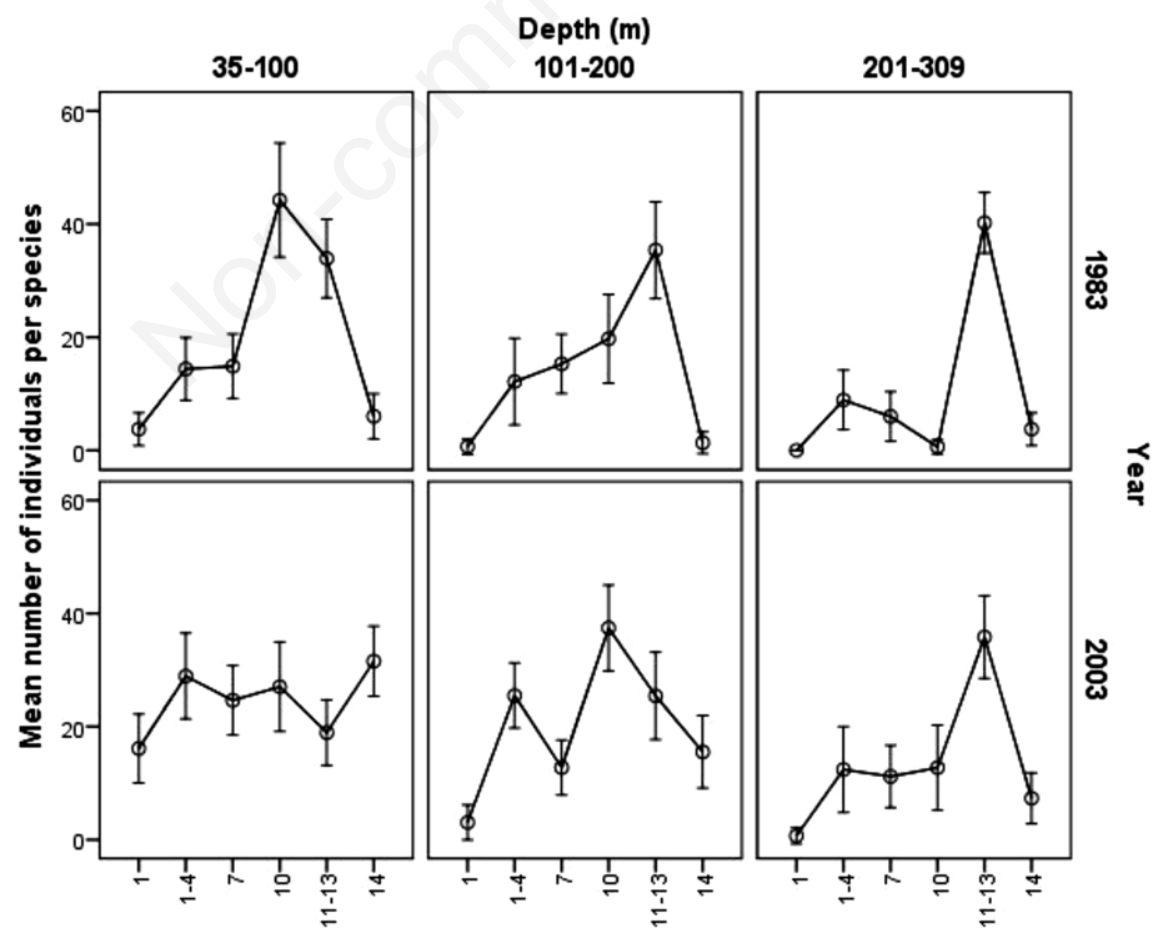

Fig. 8. The y axis indicates how the mean numbers $\mathrm{m}^{-2}$ with $95 \%$ confidence interval (square root transformed) of individuals of species or groups of species varies with depth between 1983 and 2003 in Lake Geneva (area 8, Fig. 1). The digits on the x axis correspond to the name of species on Tab. 1. Digit 14 denotes the mean numbers of chironomids. 


\section{Local variations of sedimentation}

In Lake Memphremagog (Rasmussen and Rowan, 1997), the deposition of fine sediment varied strongly from place to place, as in the Small Lake, thus interacting with lake trophic status as determinant of benthic community composition. The thickness of fine sediment increased according to exposure to the prevailing winds (fetch) but it decreased if bottom slope increased. In the above study, the deposits of fine sediment at least $10 \mathrm{~cm}$ thick or more were found to be depositional, those less than $10 \mathrm{~cm}$ were rather erosional. In my study, if the thickness of the black layer increased above the median value of $10 \mathrm{~cm}$ measured in 186 cores, the composition of zoobenthos changed also, indicating a transition from oligotrophic to mesotrophic-eutrophic conditions (Tab. 4, columns 5 and 6).

In the Small Lake, the fetch resulting from the northeast winds increased strongly westward from basin 3 to 1. In contrast, the bottom slope, which increased from basin 3 to 1 , has less effect on my results because most of the cores were collected on a flat bottom, far from steep slopes. As a consequence, the increasing thickness of the black layer within the sediment followed the same westward trend. In contrast to the three basins, the black layer was very thin in area 4 because of the strong currents which swept across the sill separating the Small Lake from the Large Lake (Umlauf and Lemmin, 2005). These authors also observed that, after episodes of strong winds from the northeast and the southeast, exchange flows were able temporarily halve or double the hypolimnetic volume of the Small Lake, thus leading to an irreversible exchange of up to $40 \%$ of the hypolimnetic water. Therefore, the impact of temperature variations on the zoobenthos must be greater in the Small Lake than in the Large Lake.

In the present study, the relationship between the thickness of the black layer and the relative abundance of sensitive oligochaete species confirms that the assessment of trophic state based on zoobenthos depends on the intensity of organic sedimentation observed in the studied sites. In 1999, as the total phosphorus concentration was $22.3 \mathrm{mg} \mathrm{m}^{-3}$ in the water, the mean percentage of individuals belonging to sensitive oligochaete species (SS1) was predicted be around $40.8 \%$ in the whole profundal of the Small Lake (Lang 1990). But the values observed were close to or higher than $40.8 \%$ only in the areas in which the thickness of the black layer was less than $10 \mathrm{~cm}$. Indeed, the highest value (69\%) was recorded in area 4 (sampled in 2006, total phosphorus $21.3 \mathrm{mg} \mathrm{m}^{-3}$ ) where the mean thickness of the black layer was $2.5 \mathrm{~cm}$.

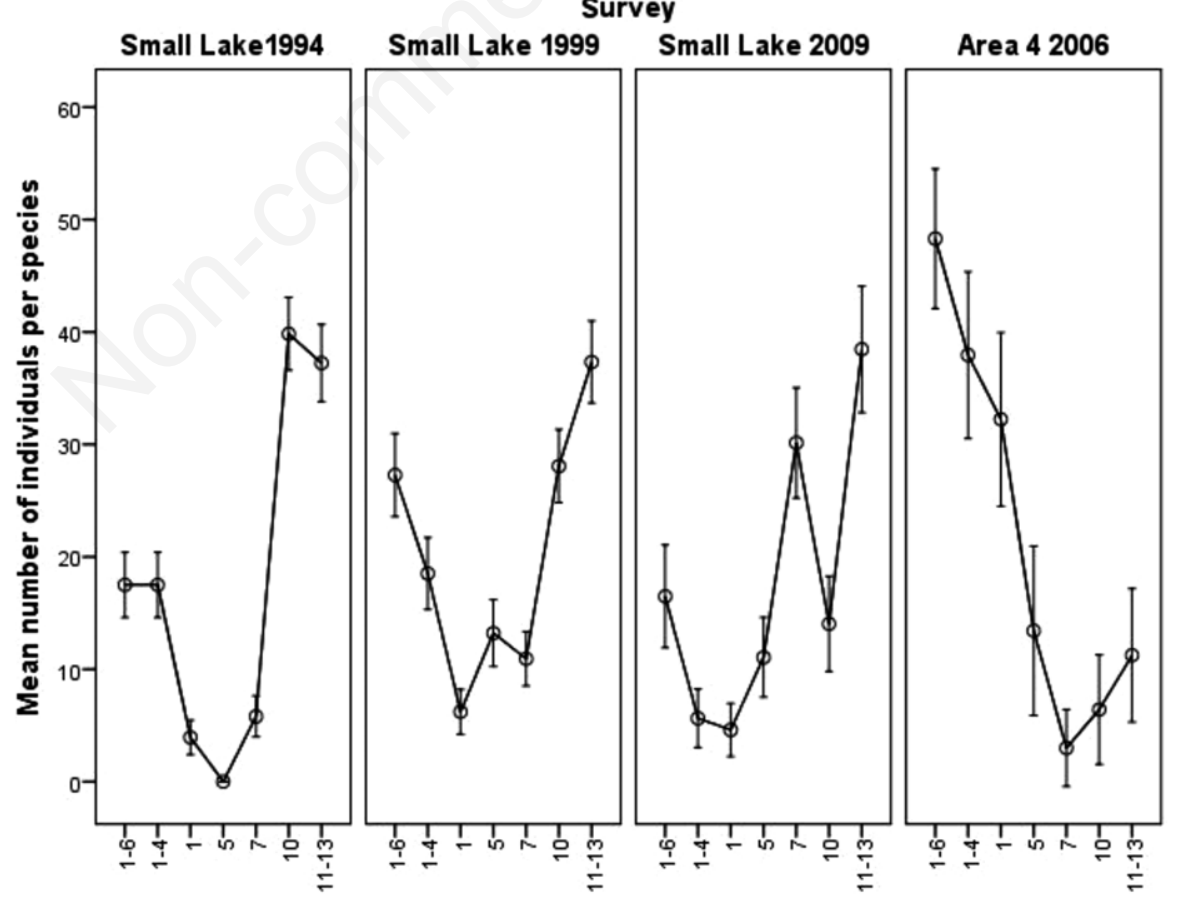

Fig. 9. Variations of mean numbers of individuals $\mathrm{m}^{-2}$ with $95 \%$ confidence interval (square root transformed) of species or groups of species indicated by the digits on the $\mathrm{x}$ axis (for the names corresponding to the digits, see Tab. 1). Three surveys were conducted in the Small Lake in $1994(\mathrm{n}=159), 1999(\mathrm{n}=159), 2009(\mathrm{n}=22)$. Jonckheere-Terpstra test for trend (probability) for species 1-4 (0.467), 1 (0.010), 7 (0.000), $10(0.000), 11-13(0.803)$. The numbers for the area 4 visited in $2006(\mathrm{n}=27)$, the sill separating the Small Lake from the Large Lake (Fig. 1), are indicated as a reference for areas of low organic sedimentation which correspond to oligotrophic conditions. 
This value $(69 \%)$ is close to the mean value $(70 \%)$ observed in the profundal zone of Lake Superior (Canada and USA) used previously as a reference for oligotrophic conditions (Lang 1990). Note that Stylodrilus heringianus was the most abundant oligochaete species in this very cold lake. In contrast, this species was not abundant in Lake Geneva in 1955 when this lake was still oligotrophic.

\section{The changing composition of zoobenthos in 2009}

Relationships established between zoobenthos and the thickness of the black layer within the sediment, used as a proxy for organic sedimentation, indicated that the abundance of $P$. vejdovskyi was positively correlated with the increase of organic sedimentation. However, the decrease of this species in 2009 could not be attributed to the decrease of organic sedimentation because the abundance of the very tolerant species did not decrease at the same time as in the Large Lake, $150 \mathrm{~m}$ deep, from 1990 to 2005 (Lang, 2009). This suggested rather a deterioration of the oxygen conditions at the water-sediment interface which has affected more this species and the sensitive oligochaete species than the other species.

This interpretation (Lods-Crozet, 2011) was supported by the fact that the biomass of phytoplankton has increased in the Small Lake from 2001 to 2009 (Lavigne et al., 2011). In addition, this increase was due to large-size algae, such as Mougeotia gracillima, which are more likely to settle intact on the bottom than smaller species. The selective predation of fish on large-size zooplankton could explain why the biomass of large-size planktonic algae has increased between 2001 and 2009 (Tadonléké et al., 2009), thus providing more food for the chironomids that feed at the surface of sediment.

\section{The increase of warm water species}

The increased abundance of Limnodrilus and Micropsectra may be in response to the long-term increase of the temperature of water in Lake Geneva (Anneville et al., 2013). This interpretation was confirmed for Micropsectra by the results of a field experiment (Tixier et al., 2009) in which the water temperature was increased (mean increase $4.8^{\circ}$, range $3.8-6.3^{\circ}$ ) in one portion of a groundwater outflow (a spring) whereas it was unchanged in the other one. As a consequence, the abundance of Micropsectra, which was the most abundant chironomid, did not decrease in response to increasing water temperatures, contrary to the other cold stenothermal taxa present. In addition, as Micropsectra increases its respiration rate with decreasing oxygen availability until a critical point, it can tolerate low oxygen conditions better than other sensitive chironomid taxa (Brodersen et al., 2008).

The abundance of the Limnodrilus species did not increase in response to the increase of organic sedimentation in the two studies presented at the beginning of this Discussion section. These sites, which were located at a depth of $35 \mathrm{~m}$ and $40 \mathrm{~m}$ respectively, were sampled in 1980 and 1987 when the water of Lake Geneva was cooler than it was in 2009 (Tab. 2). This suggests that their abundance was limited at this time by the lower water temperature. Indeed, the number of eggs produced by L. hoffmeisteri increased with temperature under laboratory conditions as demonstrated for tropical populations (Nascimento and Alves 2009). Other experiments have shown that temperate populations of L. hoffmeisteri and T. tubifex can tolerate higher temperatures, longer periods of anoxia, and more organic pollution than Stylodrilus heringianus, a species of cold oligotrophic lakes (Chapman et al., 1982).

The increase of these two warm water taxa, as well as the decrease of sensitive oligochaete species was first observed between 1992 and 1997 (Lang, 1999) in Lake Neuchâtel (215 Km² in area) located $32 \mathrm{~km}$ north of Lake Geneva. And this trend persisted in 2000 and 2002 (LodsCrozet and Reymond, 2005). This earlier change could be explained by the fact that Lake Neuchâtel is more exposed to the effects of warming because it is shallower than Lake Geneva (mean depth $60 \mathrm{~m}$ vs $150 \mathrm{~m}$ ).

In the Small Lake, the relative position of species on the factorial plot (Fig. 4) is dependent on component 1 which was correlated with the increase of organic sedimentation. In contrast, component 2 may likely reflect the long-term increase of water temperature from 1969 to 1999. The high contribution of Limnodrilus and Micropsectra to component 2 supports this interpretation (loadings 0.758 and 0.689 ) respectively. In the same way, one component of a PCA, based on the benthic community of Lake Memphremagog (Rasmussen and Rowan, 1997), is reflected in the depositional regime, which corresponds with the thickness of fine sediment, whereas the other component reflected the thermal environment. However, the effect of the thermal environment was stronger and more immediate in the above study because its sites were located both in the epilimnion and the hypolimnion (depth range: $4 \mathrm{~m}$ to $43 \mathrm{~m}$ ). In contrast, the sites of this present study, located only in the hypolimnion (depth range: $37-$ $76 \mathrm{~m}$, mean depth $60 \mathrm{~m}$ ), are exposed to the long-term increase of water temperature rather than to its seasonal variations.

\section{Less phosphorus but new stressors}

In Lake Geneva, the increase of phosphorus from 1957 to 1979 and its decrease from 1979 to 2003 predicted correctly the decrease followed by the increase of the percentage of individuals belonging to sensitive species in the oligochaete communities (Fig. 10). However, the speed of recovery decreased with depth: the recovery was rapid at a depth of $40 \mathrm{~m}$ from 1977 to 1996 , it was slower at a depth of $150 \mathrm{~m}$ from 1990 to 1998, and 
it did not occur at a depth of $309 \mathrm{~m}$ in 2003 (Lods-Crozet and Reymond, 2004). In the deepest area of Lake Geneva, the hypoxia has been triggered first by the increase of phosphorus then by climate warming (Jenny et al., 2014). The decrease of sensitive oligochaete species at a depth of $150 \mathrm{~m}$ in 2005 in the Large Lake and in 2009 in the Small Lake indicated that the positive effects of decreasing phosphorus were impeded by other stressors which have appeared during the recovery. For instance, the percentage of individuals belonging to sensitive oligochaete species was 2\% in 2009 in the Small Lake whereas the value predicted from total phosphorus concentration was around 50\% (Lang, 1990). The increase of water temperature observed between 1969 and 2009 seems to be the main factor explaining why the sensitive species of oligochaetes, characteristic of cold oligotrophic lakes, have been replaced by sensitive chironomids species which can tolerate warmer water.

In addition, the combined effects of the many micro pollutants (pesticides, drugs, and other substances) which are present in Lake Geneva could also have affected the most sensitive oligochaete species as they have negatively affected some species of planktonic algae (Gregorio et al.,
2012). Sensitive species of oligochaetes depend (Wiederholm, 1980) for their food (bacteria) and reproduction from the conditions observed within the sediment. Therefore, if these conditions change, oligochaetes are disadvantaged, compared to the chironomids, which feed within the sediment by also on its surface on algae, bacteria and detritus. In addition, the possible impact of micro pollutants on the eggs will be more important on those of the sensitive species of oligochaetes buried in the sediment than on those of chironomids deposited on its surface. Exposure essays demonstrated the impact of a mixture of 10 organic pollutants on eggs of Daphnia resting in the sediment of the Greifensee, a Swiss lake (Möst et al., 2015). Mortality and number of anomalies increased in the hatchlings whose eggs have been exposed to the pollutants. And the increase of temperature could increase the toxicity of contaminants (Guilizzoni et al., 2012).

In contrast to the more sensitive oligochaete species, L. hoffmeisteri is well adapted to the increase of pollutants in a warmer lake. Indeed this species evolved genetic resistance to high concentrations of cadmium $\left(10^{3}-10^{4} \mathrm{mg}\right.$ $\mathrm{kg}^{-1}$ ) in a polluted site (Mackie et al., 2010). This tolerant population grew rapidly at different temperatures $\left(25^{\circ} \mathrm{C}\right.$

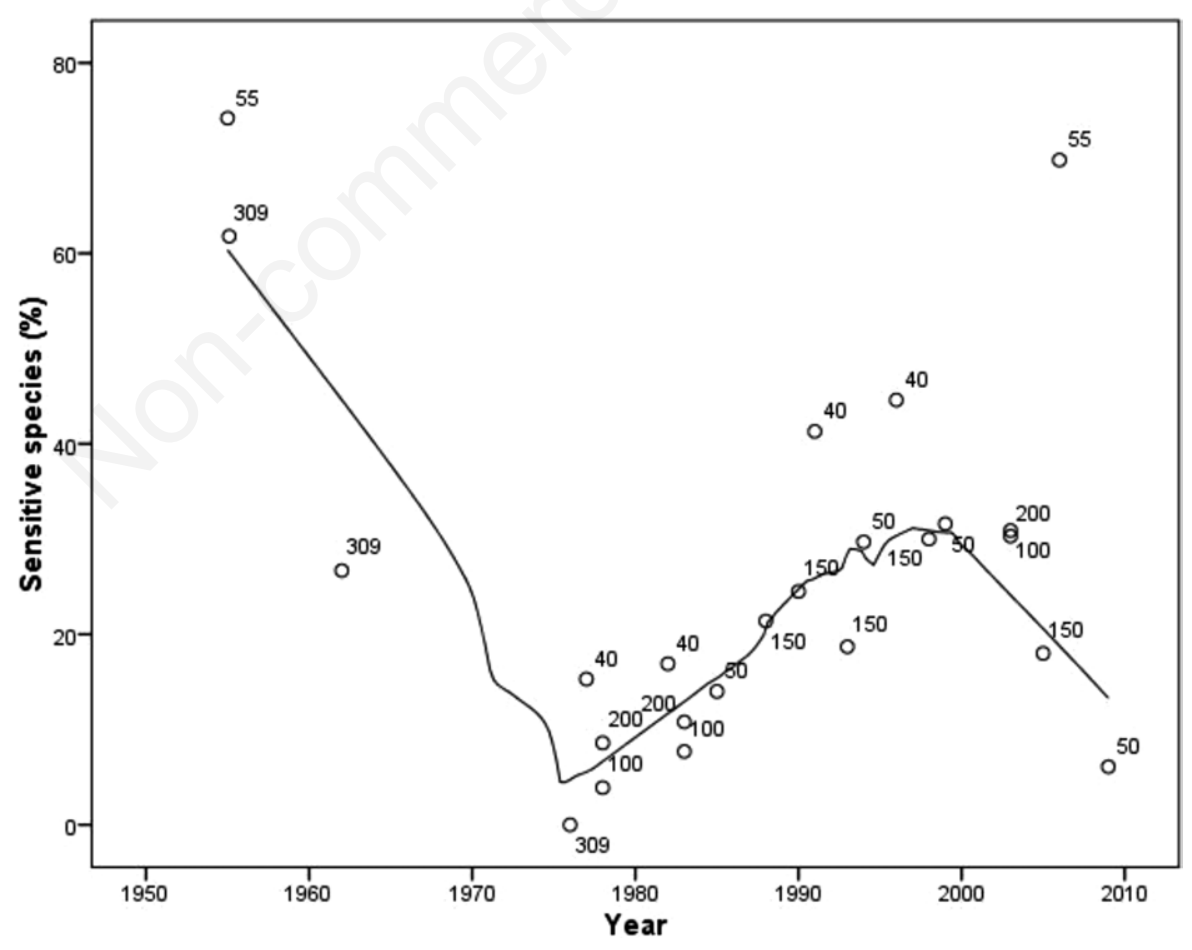

Fig. 10. Changes from 1955 to 2009 in the mean percentages of individuals belonging to sensitive species (species 1-4 Tab. 1) in the oligochaete communities of Lake Geneva. The digits near the circles denote the mean depth of each survey. Surveys made at $40 \mathrm{~m}$ and $150 \mathrm{~m}$ were located on the northern shore of the Large Lake (area 7, Fig. 1); surveys made at $100 \mathrm{~m}$ (35-100 m) and 200 m (101-200 $\mathrm{m}$ ) covered the western part of the Large Lake (Area 8); surveys made at $309 \mathrm{~m}$ represented the deepest area; surveys made at $50 \mathrm{~m}$ covered area 3 of the Small Lake; surveys made at $55 \mathrm{~m}$ represented the transition area between the Small and the Large Lake (area 4 in 2006; areas 5 and 6 in 1955). Curve based on a robust regression (Lowess) including 50\% of points. 
and $35^{\circ} \mathrm{C}$ ), indicating that its metabolism was not affected by cadmium. But this population lost its resistance to cadmium after the dredging of contaminated sediments. In $T$. tubifex, five major mitochondrial lineages differing in their resistance to cadmium have been observed (Sturmbauer et al., 1999). According to these authors, this suggests that, in the aquatic oligochaetes, natural selection acts on physiological rather than on morphological characters thus producing cryptic species. Finally, the increased impact of Coregonus fish populations on zooplankton (Tadonléké et al., 2009) could have increased the transfer of organic matter to the sediment, thus promoting hypoxic conditions even if phosphorus concentrations were relatively low. However, in the Small Lake, oxygen concentrations measured one meter above the bottom in the deepest areas (70-76 m) were always higher than $6 \mathrm{mg} \mathrm{L}^{-1}$ (Lazzarotto et al., 2011). But the oxygen conditions relevant for zoobenthic species, especially for the eggs and the juveniles, are those observed in the diffusive boundary layer (DBL) above the sediment. The thickness of DBL (0-10 mm) decreases when turbulent mixing within the bottom boundary layer (BBL) increases (Lorke et al., 2003). Furthermore, the intensity of turbulence in BBL depends on the speed of currents, as observed on the sill separating the Small Lake from the Large Lake (Umlauf and Lemmin 2005). Combined with the effects of BBL, oxygen conditions in DBL depend on the oxygen uptake by the sediment which can vary temporally and spatially. If the uptake is high and DBL thick, sediments exposed to aerated water could be almost anoxic at the surface (Jorgensen and Revsbech 1985). Thus, the oxygen uptake seems to increase with the thickness of the black layer within the sediment, as suggested by the concomitant decrease of oligochaete species sensitive to low oxygen concentrations. Because oxygen uptake by sediment increases with the water temperature (Jorgensen and Revsbech 1985), these sensitive species will be the first affected in a warmer lake.

\section{CONCLUSIONS}

From 1983 to 2003, sensitive species of oligochaetes increased in Lake Geneva as expected from the decrease of phosphorus (Lang, 1990). However, in 2005 and again in 2009, several new stressors (climate warming mostly, fish predation on zooplankton certainly, and micro pollutants probably) began to interact at different levels, modifying the pelagic-benthic coupling during the recovery from manmade eutrophication. As described by Guilizzoni et al. (2012) for the pelagic communities of Lake Maggiore, the climate warming have the same effects on sensitive oligochaete species of Lake Geneva and Lake Neuchâtel as those resulting from an increase of eutrophication. Therefore, prospects for a full restoration of the oligochaete community present in 1955 are poor indeed, except in the areas where the organic sedimentation is decreased by strong currents or by steep bottom slope. The rarity of sensitive oligochaete species observed in 2009 indicates that the biological properties within the deep sediments have drastically changed. Sensitive species of chironomids are less affected probably because they depend more on the surface of sediment than on its deeper layers.

\section{ACKNOWLEDGMENTS}

I thank Ulrich Lemmin, Mark Wetzel, and two anonymous reviewers for their useful comments. This study is based on results collected and analysed by the environmental service of the canton of Vaud (Direction Générale de l'Environnement).

\section{REFERENCES}

Alric B, Jenny J-P, Berthon V, Arnaud F, Pignol C, Reyss JL, Sabatier P, Perga ME, 2013. Local forcings affect lake zooplankton vulnerability and response to climate warming. Ecology 94:2767-2780.

Anneville O, Beniston M, Gallina N, Gillet C, Jacquet S, Perroud $\mathrm{M}, 2013$. [L'empreinte du changement climatique dans le Léman].[Article in French]. Arch. Sci .66:157-172.

Brandl H, Hanselmann KW, Bachofen R, Piccard J, 1993. Small-scale patchiness in the chemistry and microbiology of sediments in Lake Geneva, Switzerland. J. Gen. Microbiol. 139 2271-2275.

Brodersen KP, Pedersen OLE, Walker IR, Jensen MT, 2008. Respiration of midges (Diptera; Chironomidae) in British Columbian lakes: oxy-regulation, temperature and their role as palaeo-indicators. Freshwater Biol. 53:593-602.

Chapman PM, Farrell MA, Brinkhurst RO, 1982. Relative tolerances of selected aquatic oligochaetes to individual pollutants and environmental factors. Aquat. Toxicol. 2:47-67.

Fuentes N, Güde H, Straile D, 2013. Importance of allochthonous matter for profundal macrozoobenthic communities in a deep oligotrophic lake. Int. Rev. Hydrobiol. 98:1-13.

Gerdeaux D, 2004. The recent restoration of the whitefish fisheries in Lake Geneva: the roles of stocking, reoligotrophication, and climate change. Ann. Zool. Fennici 41:181-189.

Gregorio V, Büchi L, Anneville O, Rimet F, Bouchez A, Chèvre N, 2012. Risk of herbicide mixtures as a key parameter to explain phytoplankton fluctuation in a great lake: the case of Lake Geneva, Switzerland. Ecotoxicology 21:2306-2318.

Guilizzoni P, Levine SN, Manca M, Marchetto A, Lami A, Ambrosetti W, Brauer A, Gerli S, Carrara A, Rolla A, Guzzella L, Vignati AL, 2012. Ecological effects of multiple stressors on a deep lake (Lago Maggiore, Italy) integrating neo and palaeolimnological approaches. J. Limnol. 71:1-22.

Hutter P, Lang C, 1981. Sedimentary inputs and oxygen uptake by the sediment in Lake Geneva (Switzerland). Schweiz. Z. Hydrol. 43:253-264.

Jenny JP, Arnaud F, Alric B, Dorioz JM, Sabatier P, Meybeck M, Perga ME, 2014. Inherited hypoxia: A new challenge for reoligotrophicated lakes under global warming. Global Biogeochem. Cy. 28:1413-1423.

Jørgensen BB, Revsbech NP, 1985. Diffusive boundary layers 
and the oxygen uptake of sediments and detritus. Limnol. Oceanogr. 30:111-22.

Juget J, 1958. [Recherches sur la faune de fond du Léman et du lac d'Annecy].[Article in French]. Ann. Station Centr. Hydrob. Appl. 7:10-95.

Lang C, 1985. Eutrophication of Lake Geneva indicated by the oligochaete communities of the profundal. Hydrobiologia 126:237-243.

Lang C, 1989. Effects of small-scale sedimentary patchiness on the distribution of tubificid and lumbriculid worms in Lake Geneva. Freshwater Biol. 21:477-481.

Lang C, 1990. Quantitative relationships between oligochaete communities and phosphorus concentrations in lakes. Freshwater Biol. 24:327-334.

Lang C, 1999. Contrasting responses of oligochaetes (Annelida) and chironomids (Diptera) to the abatement of eutrophication in Lake Neuchâtel. Aquat. Sci. 61:206-214.

Lang C, 2000. [Réponse des communautés d'Oligochètes (Tubificidés et Lumbriculidés) et de Diptères Chironomides à la baisse des teneurs en phosphore dans le Léman (Petit Lac)].[Article in French]. Ann. Limnol. 36:13-20.

Lang C, 2009. [Indices basés sur les oligochètes et les chironomides indiquant la restauration écologique des sédiments du Léman].[Article in French]. Bull. Soc. Vaud. Sc. Nat 91:283-300.

Lang C, Hutter P, 1981. Structure, diversity and stability of two oligochaete communities according to sedimentary inputs in Lake Geneva (Switzerland). Schweiz. Z. Hydrol. 43:265-276.

Lavigne S, Cordonier A, Jaquet JM, 2011. Evolution du phytoplancton du Petit Lac (Léman)], p. 109-124.[Report in French]. Rapp. Comm. Int. Protection des eaux de Léman contre la Pollution, Lausanne.

Lazzarotto J, Nirel P, Rapin F, 2011. [Évolution physico-chimique des eaux du Léman (éléments majeurs)], p. 226-50. [Report in French]. Rapp. Comm. Int. Protection des eaux de Léman contre la Pollution, Lausanne.

Lods-Crozet B, 2011. [Evolution du zoobenthos du Léman (Petit Lac)], p. 143-150. [Report in French]. Rapp. Comm. Int. Protection des eaux de Léman contre la Pollution, Lausanne.

Lods-Crozet B, Reymond O, 2004. [Réponses des communautés benthiques du Léman à l'amélioration de l'état trophique du Léman entre 1983 et 2003], p. 99-109.[Report in French]. Rapp. Comm. Int. Protection des eaux de Léman contre la Pollution, Lausanne.

Lods-Crozet B, Reymond O, 2005. Ten years trends in the oligochaete and chironomid fauna of Lake Neuchâtel (Switzerland). Rev. Suisse Zool. 112:543-58.
Lods-Crozet B, Reymond O, 2006. [Evolution du zoobenthos profond du Léman], p. 141-146. [Report in French]. Rapp. Comm. Int. Protection des eaux de Léman contre la Pollution, Lausanne.

Loizeau J-L, Edder P, De Alencastro LF, Corvi C, Ramseier Gentile S, 2013. [La contamination du Léman par les micropolluants-Revue de 40 ans d'études].[Article in French]. Arch. Sci. 66:117-136.

Lorke A, Müller B, Maerki M, Wüest A, 2003. Breathing sediments: The control of diffusive transport across the sediment water interface by periodic boundary-layer turbulence. Limnol. Oceanogr. 48:2077-2085.

Mackie JA, Levinton JS, Przeslawski R, Delambert D, Wallace W, 2010. Loss of evolutionary resistance by the oligochaete Limnodrilus hoffmeisteri to a toxic substance-cost or gene flow? Evolution 64:152-165.

Möst M, Chiaia-Hernandez AC, Frey MP, Hollender J, Spaak P, 2015. A mixture of environmental organic contaminants in lake sediments affects hatching from Daphnia resting eggs. Environ. Toxicol. Chem. 34:338-345.

Nascimento HL, Alves RG, 2009. The effect of temperature on the reproduction of Limnodrilus hoffmeisteri (Oligochaeta: Tubificidae). Zoologia 26:191-193.

Rasmussen J, Rowan D, 1997. Wave velocity thresholds for fine sediment accumulation in lakes, and their effect on zoobenthic biomass and composition. J. N. Am. Benthol. Soc. 16:49-65.

Schindler D, 2009. Lakes as sentinels and integrators for the effects of climate change on watersheds, airsheds, and landscapes. Limnol. Oceanogr. 54:2349-2358.

Sturmbauer C, Opadiya GB, Niederstätter H, Riedmann A, Dallinger R, 1999. Mitochondrial DNA reveals cryptic oligochaete species differing in cadmium resistance. Mol. Biol. Evol. 16:967-74.

Tadonléké RD, Lazzarotto J, Anneville O, Druart J-C, 2009. Phytoplankton productivity increased in Lake Geneva despite phosphorus loading reduction. J. Plankton Res. 10:1179-1194

Tixier G, Wilson KP, Williams DD, 2009. Exploration of the influence of global warming on the chironomid community in a manipulated shallow groundwater system. Hydrobiologia 624:13-27.

Umlauf L, Lemmin U, 2005. Interbasin exchange and mixing in the hypolimnion of a large lake: The role of long internal waves. Limnol. Oceanogr. 50:1601-11.

Wiederholm T, 1980. Use of benthos in lake monitoring. J. Water Poll. Control Fed. 52:537-47. 